\title{
Mundos do trabalho no Amazonas: as lideranças operárias socialistas - Joaquim Azpilicueta, Nicodemos Pacheco, Manoel Sérvulo e Cursino da Gama (1914-1928)
}

\author{
Labor worlds in Amazon: socialist worker leaderships - Joaquim \\ Azpilicueta, Nicodemos Pacheco, Manoel Sérvulo and Cursino da \\ Gama (1914-1928)
}

\section{Luciano Everton Costa Teles ${ }^{1}$}

\section{RESUMO}

O presente artigo tem como finalidade explicitar a atuação de quatro lideranças operárias socialistas no Amazonas que marcaram presença na produção de jornais, na organização de associações de trabalhadores e na fundação de um partido operário entre os anos de 1914 e 1928. Para esse propósito a imprensa operária foi peça documental fundamental, pois em suas páginas ficaram impressas informações sobre a parcela organizada dos trabalhadores, tornando possível, então, observar os referidos militantes.

Palavras-chave: Três. Palavras. Chave.

\section{ABSTRACT}

The purpose of this article is to make explicit the work of four socialist workers' leaders in Amazonas who were present in the production of newspapers, in the organization of workers' associations and in the founding of a workers' party between 1914 and 1928. For this purpose the press was a fundamental documentary piece, because in its pages information was printed on the organized part of the workers, making it possible then to observe the mentioned militants.

Keyword: Labor press. Socialist leaders. Worlds of work. Amazonas.

1 . Universidade do Estado do Amazonas/CEST. Doutorando em História pela Universidade Federal do Rio Grande do Sul(UFRGS). e-mail: lucianoeverton777@hotmail.com 
Recentemente a imprensa operária tem sido retomada mediante uma perspectiva metodológica que a explora enquanto objeto e fonte de estudo concomitantemente (GONÇALVES, 2001, p. 9-10). Certamente que os estudos históricos nos anos de 1980, a denominada década de ouro da história operária, demonstraram a importância dos jornais voltados aos trabalhadores, em especial como documentos históricos capazes de permitir análises relacionadas à vida operária, seja no espaço de trabalho (ARAVANIS, 2010) e/ou no cotidiano (DECCA, 1997).

Foram vários os autores que alertaram acerca da potencialidade da imprensa para a investigação histórica. Em 1985, por exemplo, Zicman já acentuava que os jornais eram bastante consultados e citados, porém raramente estudados e analisados (ZICMAN, 1985). Nesse mesmo ano, Rago apontou que a riqueza da imprensa, particularmente a operária, não estava ligada somente aos aspectos materiais e de luta dos trabalhadores, mas incluía perspectivas culturais e propostas de uma nova sociedade (RAGO, 1985). Atualmente, estudiosos que se debruçam sobre esse tipo de documentação, como Luca (2008), continuam assinalando o valor dessa documentação para a pesquisa histórica.

Destarte, os jornais se mostraram extremamente fertéis como fonte histórica, notadamente ricos em informações acerca dos ideais de luta dos operários, das suas denúncias, das suas demandas, dos seus projetos políticos, das suas ações de luta, do seu lazer, da sua moradia, dentre outros aspectos.

Como objeto de estudo, as diversas pesquisas executadas, em linhas gerais, procuraram pensá-los a partir da sua historicidade e em articulação com os processos de incorporação de novas tecnologias e linguagens (BAHIA, 1990) e/ou de discutí-los através da sua dinâmica e evolução, analisando suas características em diversos contextos históricos, descortinando seus conteúdos políticos e ideológicos (SODRÉ, 1999) e/ou percebendo-os como parte integrante do tecido social, sofrendo e intervindo nas questões sociais (CRUZ, 2000).

Produzida por militantes, que tomaram para si a responsabilidade de elaborá-la e fazêla circular nos espaços urbanos de várias capitais brasileiras no decorrer da Primeira República, a imprensa operária, para melhor ser compreendida em sua complexidade, deve ser investigada considerando o tripé realçado por Ferreira, ou seja, as folhas operárias precisam ser vinculadas às suas lideranças, às suas associações e, no caso dos socialistas, aos partidos operários aos quais estavam umbilicalmente ligadas (FERREIRA, 1988, p. 13-14).

Nesse sentido, a proposta metodológica indicada no início do texto não somente permite essa junção na exploração da imprensa operária, como objeto e fonte ao mesmo tempo, como também oportuniza uma visão de conjunto, potencializando um entendimento mais articulado entre os seus protagonistas e as ideias que faziam circular no interior de um 
contexto histórico específico. Como salientou Gonçalves, é primordial compreender a imprensa como um:

[...] instrumento de intervenção na vida social em que seu estudo pode se dar como objeto/fonte, uma vez que desaparece a categoria imprensa na forma abstrata para dar lugar ao movimento vivo das idéias, protagonistas e, principalmente, para que emerjam dessa produção de sentidos, como resultado da operação histórica, sujeitos dotados de consciência determinada na prática social (GONÇALVES, 2001, p. 9).

Não se pode negar que as diferenças político-ideológicas se materializavam em diferentes caminhos de luta no interior do movimento operário, o que gerava disputas pelo seu controle. Nesse ínterim, o caminho de luta e os repertórios de ação traçados pelos sindicalistas revolucionários, por exemplo, possuem significativas diferenças daqueles elaborados pelos socialistas. Em que pese essas disputas, que são componentes do universo do trabalho e que estão registrados na imprensa operária, constituindo-se como temas de estudo (SCHMIDT, 2000), os trabalhadores organizados buscaram construir estratégias de luta que promovessem justiça social.

O objetivo deste artigo consiste em explicitar a atuação de quatro lideranças operárias socialistas no Amazonas - Joaquim Azpilicueta, Nicodemos Pacheco, Manoel Sérvulo e Cursino da Gama - que marcaram presença na produção de jornais, na organização de associações de trabalhadores e na fundação de um partido operário entre os anos de 1914 e 1928. Esses personagens se constituem como lideranças no sentido atribuído por Batalha, ou seja, como militantes que não se restringiam apenas as suas categorias profissionais, mas que procuravam atingir os operários em seu conjunto, atuando de forma substancial na produção, sustentação e circulação de uma imprensa, através da qual procuravam difundir suas interpretações sociais e seus projetos de participação política. ${ }^{2}$

\section{Mundos do trabalho no Amazonas na Primeira República}

\footnotetext{
${ }^{2}$ Para o autor, a militância operária nunca foi homogênea, pois estaria dividida em uma série de correntes políticas e sindicais, além de assumir diferentes comprometimentos. Evidenciando essa heterogeneidade, e ciente que as tipologias podem criar mais problemas que soluções, o autor distinguiu três tipos de militantes. Além das lideranças, os quadros intermediários (grupo maior que participa ativamente da vida da categoria, integra direções de associações, assina manifestos, porém pouco escreve sobre suas práticas e muito menos produz teorias) e os militantes de base (os mais numerosos, os que exercem uma militância eventual, em especial em momentos de ascensão dos movimentos) (BATALHA, 1997, p. 93).
} 
O mercado de trabalho na capital do Amazonas ampliou-se significativamente por força da expansão da economia da borracha. Isso porque embora a produção da goma elástica se desse no interior, nos seringais espalhados na floresta amazônica, era na cidade de Manaus que ocorria a sua comercialização. Nela foi edificada uma infraestrutura necessária para o escoamento dessa produção, gerando, então, uma gama de atividades econômicas ligadas à circulação, consumo e serviços (transportes, limpeza pública, água, luz, esgoto, etc.).

O capital inglês não só se fez presente em Manaus como se tornou o maior responsável pela execução dos projetos de reforma da cidade (DIAS, 1999, p. 50). Os serviços urbanos, por exemplo, ficaram nas mãos dos ingleses, que os ampliaram e, em alguns casos, até mesmo criaram. Empresas como a Manáos Markets, Manáos Tramways and Light, Manáos Improviments, Manáos Harbour, Amazon Engineering, Amazon Telegraph, Booth Line e Amazon River passaram a estabelecer relações cotidianas com a população local (PINHEIRO, 1999, p. 42).

Manaus, a partir de então, passou a assumir a função de centro comercial da borracha, rivalizando com Belém. Dessa forma, atuando no seu espaço urbano, tem-se as firmas estrangeiras que administravam os serviços urbanos, além da praça comercial que aumentou sua dimensão, diversificando-se. Desse modo, estabelecimentos comerciais passaram a oferecer produtos nacionais e importados, assim como um conjunto variado de serviços (hotéis, restaurantes, botequins, etc.).

A cidade passou a presenciar o surgimento e/ou a ampliação de marcenarias, sapatarias, alfaiatarias, fábricas de tecido, fábricas de roupas, fábricas de cestas e vassouras, funilarias, tabacarias, panificadoras, fábricas de cerveja e gelo, fábricas de sabão e outros (COSTA, 2000, p. 53). Enfim, os setores econômicos desenvolvidos, na esteira da exportação da borracha, tinham como alicerces as atividades de circulação e serviços, havendo a atuação, em pequena escala, de oficinas/fábricas específicas. O mercado de trabalho manauara se configurou ancorado nessas bases. ${ }^{3}$

Tanto os trabalhadores nacionais quanto os estrangeiros que se deslocaram para a região, através de um processo imigratório, inseriram-se enquanto força de trabalho nas atividades econômicas acima salientadas. Portanto, tornaram-se cigarreiros, ferreiros, caixeiros, construtores civis, padeiros, carroceiros, estivadores, condutores de bondes, dentre outras categorias que emergiram nesse processo de transformações econômicas da cidade.

\footnotetext{
${ }^{3}$ Não se deve deixar de apontar também que o aparato burocrático do estado se ampliou e absorveu profissionais para seus serviços na área da saúde, da educação, do policiamento, etc. Sobre este ponto consultar (PINHEIRO, 2011, p. 12).
} 
Cabe assinalar que nem de longe se quer afirmar que a classe trabalhadora emergiu dessa estrutura econômica de forma mecânica, como algo derivado dela. Pelo contrário, entende-se a classe na esteira de Thompson, ou seja, como um fenômeno político e cultural, cujo fazer-se ocorre numa perspectiva histórica e relacional. Esse caráter relacional é importante, assim como também são as condições materiais de existência e como elas são percebidas e experimentadas pelos trabalhadores, que, através delas, constroem as suas instituições de classe e a sua luta política (THOMPSON, 1987, p. 9-10).

Essas instituições (e a luta política) foram estabelecidas por militantes operários no Amazonas. Assim, três correntes político-ideológicas marcaram presença na região: o anarquismo, na vertente do sindicalismo revolucionário, o socialismo e o colaboracionismo. O comunismo não se fez presente nesses anos, nem quando da fundação no Brasil do Partido Comunista, em 1922. As lideranças operárias no Amazonas eram majoritariamente socialistas e reformistas.

Dessa forma, no texto em tela, optou-se por realizar um recorte considerando os socialistas, especialmente quatro personagens que constantemente apareciam na imprensa operária como redatores, fundadores de associações operárias e partidos operários. Esses personagens se cruzaram em suas trajetórias e, em alguns momentos, juntos, traçaram um caminho de luta para os trabalhadores amazonenses. São eles: Joaquim Azpilicueta, Nicodemos Pacheco, Manoel Sérvulo e Cursino da Gama. Mas, antes de apresentá-los, é necessário falar do socialismo no Amazonas.

\section{O socialismo entra em cena no Amazonas: os jornais Gutenberg (1891) e Operário (1892)}

Um dos primeiros grupos compostos por lideranças socialistas se reuniu em torno dos jornais Gutenberg e Operário. O primeiro entrou em cena em 15 de novembro de 1891. Nasceu ligado à categoria dos gráficos, especialmente os tipógrafos, como periódico noticioso e literário. Porém, no lançamento do número 19, apareceu como órgão do Partido Operário. Foi alvo de violenta repressão por força das posições políticas assumidas, que caminhavam na contramão da ordem econômica, política e social vigente, sendo, por isso, impedido de continuar circulando. O segundo passou a existir no ano de 1892. Era a continuação do primeiro, com outro nome e formato, ou seja, o mesmo grupo que estava por trás do Gutenberg agora havia lançado o Operário. Mas que grupo era esse? 
Observando esses dois jornais foi possível identificar alguns personagens que foram importantes por difundirem as ideias socialistas no Amazonas. A grande maioria deles atuava na produção/colaboração do jornal e no partido operário. São eles: Raymundo Pinto de Vasconcelos (redator e $1^{\circ}$ Secretário do partido), Izidoro Vieira (redator e $2^{\circ}$ Secretário), Francisco Alves Medeiros, Vicente L. de Paula Galvão e Antônio Leão (todos mencionados como redatores e membros do Conselho de Diretores do partido), Marcellino da Exaltação Fernandes (redator e orador), Joaquim Carvalho (Presidente), João Diniz Gonçalves Pinto (Vice-Presidente), José Gonçalves Dias (Tesoureiro), J. A. de Figueiredo Castro, Gervásio Jorge dos Reis e Joaquim Pinto dos Santos (Membros do Conselho de Diretores) (GUTENBERG, 1892b).

Alguns desses indivíduos eram comerciantes e donos de oficinas, como João Diniz de Carvalho Pinto e José Gonçalves Dias. Outros eram empregados no comércio, como Antônio Leão e Izidoro Vieira, e gráficos, como Vicente L. de Paula Galvão (TELES, 2015, p. 24). O socialismo que eles defendiam e difundiam tinha como referência a II Internacional. Criada em 1889 para ser a organização internacional dos trabalhadores, a II Internacional, no início do século $\mathrm{XX}$, encontrava-se dividida em ao menos três correntes ideológicas: uma revolucionária, uma moderada e outra que defendia a adaptação à democracia burguesa. Não era, portanto, homogênea como nunca foi homogêneo o movimento operário. A II Internacional contou inclusive com a presença de Engels em seus quadros iniciais, e de Lênin, Trotsky e Rosa Luxemburgo no início do $\mathrm{XX}$, todas figuras socialistas revolucionárias. Esses últimos ficaram na II Internacional até a ruptura definitiva no contexto da Primeira Grande Guerra quando se revelou a adaptação da socialdemocracia à democracia burguesa.

Nesse sentido, não havia homogeneidade e nem um socialismo "puro" no ambiente europeu. Da mesma forma, no Amazonas, pela própria característica do movimento operário local da época, não se percebeu um comportamento rígido norteado pela perspectiva ideológica escolhida pelas lideranças operárias. Ou seja, não se pode classificar a militância de forma inflexível. Ao contrário, ao tomar como base os artigos produzidos pelos militantes no Amazonas, observou-se uma mistura de autores, obras e argumentos que se por um lado evidencia uma "mistura de elementos ideológicos", por outro demonstra como eles, fundamentados nessas correntes (socialismo, anarquismo...), pretenderam construir uma análise social que respondesse às questões que eram levantadas no universo do trabalho urbano local e que servisse para a construção de estratégias para a luta operária.

Nesse quadro, entre os socialistas, o reformismo e policlassismo surgiram como uma resposta possível no âmbito do contexto regional, o que explica, por exemplo, a presença de comerciantes e empresários em torno dos jornais e do partido operário, como destacado anteriormente. Essa característica pode ser vista também em outras regiões do país. Maciel apontou que os grupos socialistas de Maceió/AL também tinham atitudes policlassistas e 
reformistas (MACIEL, 2004, p. 121). Schmidt (2000, p. 114-119) explicitou que o socialismo de Xavier e Cavaco, importantes lideranças socialistas do Rio Grande do Sul, era "eclético", incorporando elementos das correntes de pensamento vigentes na virada do século XIX para XX. Sobre o socialismo "eclético" salientou Pansardi:

Um socialismo que constrói seu aparato teórico e seu discurso com uma ampla gama de autores de diferentes origens teóricas e políticas, e que não tem como centro a teoria de nenhum autor em especial, um socialismo que não é marxista, proudhoniano, lassaleano, maloniano, ou outro qualquer - onde muitas vezes temos dificuldades de separar as várias ideologias socialistas entre si. O socialismo eclético é, em realidade, aquele que domina entre os militantes socialistas do final do século, e mesmo entre os primeiros anos do século XX (PANSARDI, 1994, p. 69).

Um ponto que é preciso esclarecer se refere aos nossos quatro personagens socialistas. Eles desenvolveram suas ações de militância de forma mais intensa, verificadas na documentação compulsada, nos anos finais da década de 1910 e nos primeiros da década seguinte, quando, então, ocorreu no contexto mundial, como foi indicado anteriormente, uma adaptação da socialdemocracia à democracia burguesa. Como se verá mais adiante, as alianças, as eleições, os votos, a formação de um partido operário e a via parlamentar, como espaço para mudanças sociais, estarão presentes no horizonte desses militantes como ações legítimas por dentro da ordem burguesa.

Voltando para o momento da virada do século XIX para o XX, as lideranças socialistas aí situadas realizavam contatos com militantes localizados em diversas regiões do país, por meio de correspondências e permutas de jornais que dinamizavam a circulação de informações e ideias. Esses contatos foram registrados nos jornais, como se pode atestar no exemplo abaixo:

Recebemos os seguintes jornaes:

“O Purus", da Lábrea, no interior do Estado; o Humaithaense, de Humaytá, idem.

Do Pará, “Tribuna Operária”, “O Democarta”, “O Pimpão” e “Gazeta Postal". Do Maranhão: “O Artista Caxiense", “O Nacional” e o "Comércio de Caxias”. Do Piauhi, “O Democrata”. 
Da Fortaleza: "Libertados”, “O Norte”, “ O Operário”, O Bemtivi”, “Estado do Ceará", “A República”, e o “Cruzeiro de Baturité”.

Do Rio Grande do Norte: “O Povo”, e “A República”.

De Maceió: “Cruzeiro do Norte”, “Gazeta de Alagoas” e “A Troça”.

Da Bahia: "O Guarany" e "Pequeno Jornal”.

De Campos: "Monitor Campista" e "Brazil Philatelico".

De São Paulo: “A Verdade" e "Luz" e, da Capital Federal: "L'Etoile do Sul” (GUTENBERG, 1892a, p. 3).

Esses contatos geravam referências que influenciavam e/ou tentavam influenciar o movimento operário local. Nesse sentido, identificou-se o nome de José Augusto Vinhaes, expoente do partido operário do Rio de Janeiro e deputado federal (GUTENBERG,1892a, p. 3). Vinhaes foi mencionado por acompanhar e apoiar os movimentos grevistas, quando percebia sua justiça; por buscar mediar o conflito; e, uma vez não sendo realizado qualquer tipo de acordo, por procurar fortalecer o operariado em relação à burguesia, tentando impedir a violência policial, ou seja, as forças de repressão (PANSARDI, 2008, p. 97).

Mas não era somente o partido operário de Vinhaes, e ele próprio, que ganhavam as páginas dos jornais. Outras regiões e seus partidos operários, como o do estado de Alagoas, foram explicitados e tomados como referências. Sobre o partido operário de Alagoas:

Da “Troça” de Maceió de 30 de Maio transcrevemos o seguinte:

“Hontem á tarde como estava annuhciado nos jornaes da capital, teve logar na casa de residência do cidadão artista Canuto Passos, a rua do Queimado, em Jaraguá, a organisação do Partido Operário Alagoano, comparecendo a installação cidadãos de diversas classes.

Por volta de 5 horas da tarde, o cidadão Daniel Custódio, a convite da commissão encarregada da Liga Operária, occupando a cadeira de Presidente da reunião, declarou aberta a sessão inaugural do partido, ordenando em seguida que o consocio Philomeno Coelho expuzesse aos circumstantes o programma das bases do partido, que foi muito enthusiasticamente acceito" (PARTIDO..., 1892, p. 2). 
Atenta-se para o fato de que a indicação do surgimento de partidos operários em outras regiões do país se coloca, basicamente, como um convite aos trabalhadores amazonenses para efetuarem o mesmo, ou seja, criar o seu partido operário, o que foi feito, como se verá mais adiante.

Portanto, constata-se o que Batalha (1992) chamou de "construção de paradigmas" ou "modelos" elaborados para servirem de exemplos a serem seguidos e, desse modo, influenciar as organizações e ações dos operários no Amazonas, que jamais estiveram isolados no extremo norte do país. O socialismo local estava vinculado a outras regiões e umbilicalmente influenciado pela II Internacional.

Por conseguinte, mesmo nesse primeiro momento, já é possível verificar que a participação no processo político-eleitoral no interior da democracia representativa burguesa era aceito, assim como a já mencionada colaboração entre as classes e as reformas por meio de legislações específicas aprovadas no parlamento. Não foi à toa que Vicente de Paula Galvão, tipógrafo, elaborou um artigo, que foi publicado no jornal Gutenberg, solicitando o comparecimento dos companheiros em uma reunião que seria brevemente comunicada. Eis o conteúdo do texto:

Em quasi todas as capitaes do mundo têm-se operado o grande movimento artístico com os mais sublimes resultados.

A arte typographica, que, sendo como é, uma das mais importantes invenções da humanidade, deve collocar-se também na vanguarda das associações.

Em Manaós, que um typographo não é mais nem menos do que um simples artista, pode, entretanto, sahir desse marasmo, onde por tanto tempo se acha collocado.

Em São Paulo, por exemplo, que os typographos com mui diminuto numero, isto é inferior a nós aqui no Amazonas tem sabido elevar-se e elevar a classe a tal ponto de se fazer representar nos grandes movimentos populares.

Têm uma bôa associação, vivem todos bem colligados e assim têm chegado a rivalisar com muitas das melhores sociedades no sul da União.

Assim também, collegas do Amazonas, unamo-nos, que não estará talvez, muito longe o dia em que sahindo do obscurantismo em que 
vivemos, dizer ao mundo inteiro: - "Nós, os typographos, aqui no Amazonas somos grandes também; temos a nossa associação, vivemos uns para os outros e, assim unidos podemos apparecer no meio da grande e humanitaria sociedade amazonense"!

Faço, portanto, um apello nestas collumnas aos meus dedicados collegas, para comparecerem a uma reunião, que brevemente será comunicada.

No dia da reunião pede-se o comparecimento de todos (MOVIMENTO..., 1891, p. 2-3).

Não se deve deixar passar despercebida a referência que esse personagem fez aos tipógrafos de São Paulo que, certamente, existiam em quantidades maiores que os do Amazonas, porém, como se registrou anteriormente, isso fazia parte da "construção de modelos". O trecho da citação acima é importante porque pouco tempo depois foi criado o partido operário no Amazonas, certamente o primeiro de inúmeros outros que foram criados posteriormente.

Não obstante, em função da instabilidade inicial do regime republicano, especialmente com o fracasso do golpe realizado por Marechal Deodoro e, a partir daí, a ascensão de Floriano Peixoto à Presidência do Brasil, alterou-se o quadro local, uma vez que o governador do Amazonas, Thaumaturgo de Azevedo, era ligado à Fonseca e com a emergência de Peixoto foi deposto em favor de Eduardo Ribeiro. O jornal Operário apoiava Azevedo, desferindo críticas ferrenhas ${ }^{4}$ ao novo governador que não poupou esforços no sentido de perseguir, agredir e fechar o referido jornal e, talvez com ele, o nascente partido operário (TELES, 2015, p. 34-37).

\section{As lideranças socialistas no Amazonas (1914-1928)}

\footnotetext{
${ }^{4}$ Antes do seu desaparecimento, nos dois primeiros números, o jornal Operário publicou alguns artigos que teciam críticas ao governo de Eduardo Ribeiro. Uma das críticas mais robusta se deu em um artigo intitulado "Governo do Terror", de autoria de Santos Porto. Dividido em duas partes (portanto, publicado nos dois números existentes da folha), este artigo apontava, como elementos que compunham suas admoestações, as perseguições, a censura e a corrupção. Ver: Porto (1892a, 1892b).
} 
Esse primeiro momento foi significativo como experiência para o movimento operário amazonense. A difusão do socialismo no Amazonas, ocorrida nesses anos iniciais do regime republicano, atingiu outros indivíduos que, posteriormente, assumiram a responsabilidade de levar adiante a organização dos trabalhadores locais nestes termos, porém, agora, num contexto de crise econômica (que gerou falências, desempregos...) e de disputa com os sindicalistas revolucionários, cujo maior expoente local foi Tércio Miranda.

A crise econômica que se abateu sobre a região, a partir de 1910, foi fruto da entrada no mercado mundial da borracha cultivada de forma racional nas colônias britânicas na Ásia (Ceilão, Malásia, etc.), cuja produção passou a ser maior e a um custo significativamente menor em comparação com a exploração extrativa (desse produto) na Amazônia. Dessa maneira, o Amazonas, assim como Belém, foi perdendo o protagonismo econômico e comercial, o que impactou de forma significativa o universo do trabalho urbano nas duas capitais. Nas palavras de Bárbara Weinstein, foi um processo que resultou numa "longa decadência", iniciando no ano de 1910 e se agravando na década de 1920. Os quatro personagens socialistas mencionados desenvolveram suas atividades de militância fundamentalmente nessas duas décadas de crises econômicas.

Também se depararam, na década de 1910 (principalmente Joaquim Azpilicueta), com os sindicalistas revolucionários que se empenhavam em assumir o comando da organização e da ação do movimento operário no Amazonas, em especial com a chegada à região do português Tércio Miranda.

Miranda residia na cidade do Porto, no norte de Portugal. Envolveu-se com o anarquismo, entrando em contato com esta corrente ideológica mediante leituras das obras de Bakunin, Proudhon, Kropotkin, Réclus, entre outros. Como militante participou do "Grupo Aurora Social" (que nasceu em 4 de setembro de 1910), assim como, provavelmente, também colaborou na "União Geral dos Trabalhadores da Região do Norte", organização que se materializou por volta de 1912 e se tornou, pouco tempo depois, Federação Sindicalista (CRUZ, 2012, p. 32). O que acabou reforçando essa provável presença de Tércio Miranda na União foi a menção feita pelo periódico A Aurora sobre a sua participação como liderança na Liga D’Educação Nova, em $1912 .^{5}$

Com a implantação da República em Portugal (1910), cuja presença dos anarquistas foi decisiva, e a forma estritamente burguesa que assumiu, protelando a participação e os projetos sócio-políticos dos trabalhadores, o projeto anarquista, que buscava com sua ação romper com os limites impostos por um regime representativo e excludente, viu-se numa situação complicada, sendo pressionado, perseguido e tendo algumas de suas lideranças presas. Foi nesse quadro de repressão que Tércio Miranda se deslocou para o Brasil.

\footnotetext{
${ }^{5}$ Inclusive dando o endereço da Liga (Rua das Fontainhas, n. 9. Porta do Sol), o que é uma evidência forte da presença de Tércio Miranda justamente na região norte onde o anarquismo avançou.
} 
No Brasil, Miranda se inseriu como participante no Congresso Operário Brasileiro ocorrido em 1913, sob forte influência anarquista. Tornou-se delegado especial da C.O.B. na região norte, fixando residência em Manaus. Na capital do Amazonas, fundou o jornal $A$ Lucta Social (em 1914) e atuou em toda a região, especialmente em Manaus, no processo de organização dos trabalhadores na perspectiva do sindicalismo revolucionário. Passou a disputar com os socialistas o controle do movimento operário local. Dessa disputa surgiram alianças e conflitos. Nesse sentido, foi no jornal fundado pelos sindicalistas revolucionários que apareceu o nosso primeiro personagem socialista: Joaquim Azpilicueta.

\section{Joaquim Azpilicueta}

Joaquim Azpilicueta nasceu na capital de Navarra, Pamplona, na Espanha em 1890. As poucas e fragmentárias informações sobre esse personagem não permitem assinalar com precisão a sua chegada em Manaus e, muito menos, os motivos que o levaram a se deslocar para a Amazônia. Contudo, o seu envolvimento com a imprensa gerou registros significativos de sua atuação profissional e militante (PINHEIRO, 2017, p. 88). Dessa maneira, pela imprensa, sabe-se que ele era tipógrafo e importante liderança operária no Amazonas na Primeira República.

De acordo com Pinheiro, em Manaus, Azpilicueta começou na imprensa produzindo artigos numa coluna denominada "Política Española", no Jornal do Comércio. Nessa coluna ele "esboçava críticas severas à política e ao governo espanhol" (PINHEIRO, 2017, p. 89). Ainda conforme o autor, Azpilicueta se envolveu como militante "na mobilização da comunidade de seu país radicada em Manaus, resultando desse engajamento a criação da Sociedade Espanhola Beneficente, em novembro de 1908" (PINHEIRO, 2017, p. 89). Como não podia deixar de ser, recebeu as críticas de Tércio Miranda, libertário, que questionava a forma de organização dos trabalhadores em sociedades mutualistas e assistencialistas, vistas por ele como equivocadas e, sobretudo, como obstáculos que acabavam por impedir uma posição mais combatente dos operários no processo de luta social. As críticas eram contundentes, um exemplo:

Fundemos sociedades de classe, porém, não essas sociedades caçanikeis, denominada de Beneficentes - porque ellas são a negação absoluta das idéas reivindicadoras. Organizemo-nos, repito, mas dentro 
das mais modernas aspirações libertárias, nas bases sólidas do syndicalismo puro (SOMOS..., 1914, p. 2).

Nesse quadro de evidente disputa pelo controle do movimento operário local, Joaquim Azpilicueta elaborou um artigo que foi publicado no jornal A Lucta Social com o título de "impressões". Veja o teor contido no artigo:

Sou completamente contrário a luta entre os operários, porque entendo que essa luta é inglória, prejudicial e contraproducente, ante os fins que perseguimos, pois que com discussões de certo gênero, só damos ares aos elementos que devemos combater.

Sou completamente solidário com todos os que queiram concorrer a futura transformação social, dentro da evolução, chamem-se socialista de estado - grupo a que pertenço - coletivistas ou sindicalistas.

Precisamente aqui, no Amazonas, temos grande campo para propagar o socialismo, devido ao grande descuido com que os poderes públicos tratam o proletariado.

E não só os poderes públicos, ou sejam: governo, câmara, município, pouco ou nada se incomodam ante a triste situação porque atravessamos, os que produzimos mais e menos ganhamos, senão o que temos acima disso o carrasco que se chama capitalista, proprietário ou cousa que o valha que nos exige fiança de comerciantes honrados, em Manáos, para poder alugar uma casa modesta e até um pequeno quarto, coisa naturalíssima, pois nós não podemos pretender morar em palacetes com fiança de comerciantes honestos.

Agora bem: ante essa precária situação que estamos passando todos, absolutamente todos os que trabalhamos, não é triste esse espetáculo que, consciente ou inconscientemente, estão dando, para gaudio dos burgueses, esses nossos companheiros que, esquecem a confraternidade que nos deve unir, dando máo exemplo, lançando odiosidades extemporâneas.

Não, não é esse o caminho a seguir. 
Formemos em fileiras estreitas, unidas, para defender os nossos direitos, sem esquecer os nossos deveres.

Sejamos também firmes e compactos para procurar a união de todo o proletariado, educando-o, propagando as doutrinas sãs e benéficas do puro socialismo.

Acabemos com essas dissensões e, unidos, batalhemos em prol dos explorados e contra os exploradores (AZPILICUETA, 1914, p. 7-8).

$\mathrm{O}$ artigo publicado é longo, mas trás alguns elementos importantes. $\mathrm{O}$ primeiro deles trata da questão do poder público e do que seria observado como uma ausência de reponsabilidade para com os trabalhadores que, à vista disso, foram conduzidos a uma situação de abandono, com todas as suas consequências (exploração, miséria, desemprego, etc.). Segundo Azpilicueta (1914), seria esse universo adverso o "grande campo para propagar o socialismo". Isso demonstra que para esse militante o estado deveria cumprir uma função de proteção social, assegurando melhores condições de vida e trabalho para o operariado.

Todavia, já que não era isso que acontecia, caberia então aos militantes sublinharem a situação social de opressão, de exploração e de miséria que impactava o mundo do trabalho, conclamando os trabalhadores para que mudassem a sua sorte através de ações de luta. Tais ações exigiriam um esforço de solidariedade e união. Aqui se encontra o segundo elemento, pois as diferenças existentes necessitariam, para Azpilicueta, serem substituídas pela união e coesão de classe. Interessante sublinhar que ele explicita essa posição no jornal editado por Miranda (este sindicalista revolucionário e aquele socialista), talvez para servirem de exemplos a serem seguidos.

Por fim, tem-se a ideia de transformação via evolução social. Este entendimento está diretamente conectado com as ideais socialistas que entraram no Brasil e influenciaram os militantes operários. Como salientou Pansardi, o socialismo fazia parte desse caldo cultural positivista e evolucionista e é "desta forma que ele vai sendo traduzido nos meios operários." (PANSARDI, 1994, p. 82).

De fato, pelos elementos levantados por Joaquim Azpilicueta em seu artigo, constata-se uma concorrência pelo comando do movimento operário local, travada pelos militantes de diferentes perspectivas político-ideológicas, nesse caso, socialistas e anarquistas. Mas também nota-se um entendimento de que era indispensável a solidariedade e a união entre a militância para que o movimento conseguisse atingir, na esteira da evolução social, um conjunto de transformações na sociedade que superassem aquilo que era testemunhado como injustiça social. 
Desse modo, como gráfico, notadamente tipógrafo, Joaquim Azpilicueta participou da fundação do Sindicato dos Trabalhadores Gráficos (STG/AM) ao lado de Tércio Miranda, Domingos Batista Guedes, Antônio Dias Martins e Ananias Linhares da Silva (todos da Comissão Administrativa Provisória). Como liderança socialista atuou, como se pode examinar, escrevendo artigo na imprensa operária, organizando os trabalhadores em torno de associações, discursando nos meetings operários, em especial no Primeiro de Maio, como é possível averiguar na passagem abaixo:

O proletariado nacional commerorando, hoje, o Primeiro de Maio, traduz, ele de um modo inequívoco, a alegria intensa e a dor extrema que lhe vae n'alma ao relembrar a manhã rubra e trágica de muitos e muitos mezes de Maios passados. É inconteste e de vivificadoras esperanças esse movimento épico que se manifesta na multidão operaria. Seria nocuo não existir o enthusiasmo mutuo do homem trabalhador nesse dia. Se a data representa uma página de sangue, também fica em apotheose a victória das victimas em prol da collectividade. Portanto, a commemoração do dia $1^{\circ}$ é a significação admirável, é assignalar de novos horizontes, do estalar de um movimento libertador, onde se evidenciou em toda a sua pujança a coragem e o discernimento de homens que pagaram com a vida o tributo de um ideal por que pugnavam.

O operário de hoje já não é o ignorante obreiro de hontem. Já não teme o desassombro de suas idéas. Já não vive sob o influxo desolador da obediência servil. Já reconhece o valor próprio: Social; Moral; Intellectual e Physico.

São do excelso pensador Blasco Ibanez essas palavras de grande verdade: "enquanto o operário não sacudir, não arrancar, não quebrar os grilhões que os prendem e torna-o subserviente, o mundo não será perfeito". Ellas revelam o indubitável e talvez a única verdade até hoje atirada as massas trabalhistas. E porque assim pensavam em communhão com os mesmos princípios é, que, tragicamente, foram espingardeados em Chicago os mártyres do Ideal. Mas, em tudo é assim. Tem que haver victima para existir victoria. Depende um operário, em geral, de um patrão ou de alguém que se arvora a patrão. $O$ patrão explora o suor do humilde e honesto baluarte, espreitando-lhe os passos, na ância maligna e deshonesta de perseguição, de expoliação, procurando por todos os meios tornal-o um ser embrutecido, sem educação, tolhendo os seus movimentos mais extensivos capazes de 
adeantamento e instrucção. O trabalhador de hoje, porém, sacode com altivez esses movimentos torpes e vae a escola. Aprende e ensina. Comprehende e faz comprehender. Reclama o que é justo reclamar. Sabe reconhecer seus erros. Não precisa enveredar pela estrada ingrata da desordem; só tenta o justo, o possível; evita tornar indisplicente o caminho largo do Direito. Ao em vez da violência e destruição o operário actual faz uso da calma, da palavra e da ordem. E assim procedendo, e assim argumentando, tem, - o Homem Trabalhador, que é indiscutivelmente, a alavanca férrea de todas as ordens sociaes, conseguindo o fim tão aspirado, que é o da Paz, da Ordem e da Justiça.

Rememorando a data sublime, hoje, mais uma vez festejada, repito aquellas phafres patheticas: "O operário é o Mundo" (AZPILICUETA, 1928, p. 4).

Esse texto foi publicado em uma folha especial que saiu em comemoração ao Primeiro de Maio de 1928, ou seja, quatorze anos depois que ele atuou junto com o sindicalista revolucionário Tércio Miranda no jornal $A$ Lucta Social. Percebe-se uma postura diferente da anterior, na qual esse personagem passou a pregar estratégias de ação que não contrariassem a ordem política e social vigente, o que estava em consonância com a sua orientação doutrinária que, talvez, tenha sido reforçada pela perseguição e repressão, empreendidas pela elite e poder público, aos anarquistas na segunda metade da década de 1910, justificadas a partir de estereótipos como "violentos", "baderneiros" e outros.

Sobre o artigo de Azpilicueta publicado no Primeiro de Maio, verifica-se que a instrução educacional aparece no seu texto especialmente como algo negado pelo patrão. Em função disso, ela era defendida por ele, aparecendo também em outras matérias como um instrumento essencial para a emancipação operária. Ela era vista por ele como uma arma fundamental para auxiliar o operariado no processo de reflexão sobre a sociedade em que estava inserido, a sua situação social e os caminhos de luta a seguir. Certamente que isso não era uma preocupação isolada do militante em tela, constituiu-se mesmo como uma inquietação das lideranças operárias espalhadas pelo Brasil, como, por exemplo, demonstrou Bilhão para o Rio Grande do Sul, ao apontar um ponto de convergência entre anarquistas e socialistas: "a defesa da educação como arma de emancipação operária" (BILHÃO, 2015, p. 153).

Outro elemento interessante que surge no seu texto é o internacionalismo operário. Quando o autor ressalta que o "operário é o Mundo", o faz na tentativa de difundir esse caráter internacional do movimento, sendo o Primeiro de Maio a própria expressão desse processo de conexão de regiões no globo. Além disso, constata-se a valorização do trabalho 
como mote da denúncia da exploração, da injustiça social e da situação de penúria dos trabalhadores.

Ao elaborar esse artigo para o número especial de comemoração do dia Primeiro de Maio, Azpilicueta não somente tratou de recuperar historicamente o significado da data, como de sangue e de luto (aqui é notável ainda a influência da convivência com os anarquistas no ano de 1914), como também a viu como um despertar importante do operariado em direção à luta pela emancipação, numa tentativa de quebrar os grilhões e de construir um mundo mais justo e humano.

Para finalizar, concorda-se com Pinheiro quando afirma que:

Nem Tércio, nem Joaquim Azpilicueta podem ser enquadrados na categoria de meros divulgadores de ideias e doutrinas, pensadas e produzidas fora e além do contexto em que viviam e militavam. Ao contrário, seus textos e artigos partiam sempre do enfrentamento de situações concretas enfrentadas pelos trabalhadores de Manaus e, a partir de tais situações e problemas, propunham ações e reflexões que iluminavam igualmente a problemática, os temas e as questões que estavam sendo, à época, colocadas pelo debate voltado para a emancipação da classe operária (PINHEIRO, 2017, p. 99-100).

Tércio Miranda e Joaquim Azpilicueta atuaram, como já foi dito, num momento em que a economia extrativa da borracha perdeu espaço no mercado mundial, ocasionando no Amazonas falências e desempregos, lançando, dessa forma, os trabalhadores amazonenses numa situação degradante, cuja saída seria, segundo ambos, uma ação operária pautada na solidariedade, união e coesão de classe na luta por empregos, melhores salários, enfim, uma vida digna.

\section{Manoel Sérvulo}


Manoel Sérvulo foi outra liderança socialista que também marcou presença no cenário amazonense nesse período. Destacou-se participando da diretoria do Sindicato dos Cigarreiros e escrevendo artigos em folhas operárias (Vida Operária e Extremo Norte) ${ }^{6}$. Atuou ainda contribuindo para que diversas categorias fundassem seus sindicatos, a exemplo dos estivadores:

A convite do sr. Manoel Sérvulo da Silva, reuniram-se no domingo passado, grande número de estivadores no prédio $\mathrm{n}$. 38 , sito à rua Tapajós, gentilmente cedido pelo sr. Joaquim Gomes Evangelista, cuja reunião tinha por fim a organisação dessa classe.

O sr. Manoel Servulo, usando da palavra, expoz as conveniencias das organizações e os seus effeitos, em baseados argumentos, e ao terminar a sua oração, propoz aos assistentes a fundação do Syndicato de Estivadores do Amazonas, proposta esta, que foi unanimemte acceita.

Em seguida, foi aclamada a seguinte directoria: - Presidente, Targino Mariani; vice-dito, Joaquim Félix Pessoa; $1^{\circ}$ Secretário, Arthur Arruda; $2^{\circ}$ dito, Alexandre Martins do Rosário; Thesoureiro, Francisco Gomes.

Conselho fiscal: - Romão José de Lyra, Juvencio Borges da Fonseca e Joaquim Gomes Evangelista.

Após esses trabalhos, o sr. Presidente encerra a reunião, marcando outra, para hoje as 15 horas, no mesmo local, afim de ser nomeada a commissão que tem de elaborar os estatutos.

Entre os estivadores reinava grande enthusiasmo (VIDA OPERÁRIA, 1920a, p. 1).

A referida comissão foi nomeada e os estatutos foram elaborados e aprovados, consolidando a existência do novo sindicato (NOTICIÁRIO...,1920, p. 2). Sempre que tinha oportunidade, especialmente nas tribunas das associações e em momentos de comemoração de datas significativas (como o Primeiro de Maio), falava acerca das organizações operárias e de seus efeitos no processo de luta por melhores condições de vida e trabalho. Geralmente pautava a sua fala a partir das condições sociais e materiais de existência dos operários, como demonstra o exemplo a seguir:

${ }^{6}$ Como por exemplo: PALAVRAS SIMPLES. Vida Operária. Manaus, ano I, n. 6, 14/3/1920; LUCTEMOS. Extremo Norte. Manaus, ano I, n. 22, 12/6/1920; AOS PLEBEUS. Extremo Norte. Manaus, ano I, n. 37, 20/9/1920. 
Não há cousa mais triste, do que a vida do pobre trabalhador, numa quadra como esta que não há trabalho. a desgraça bate-lhe a porta e vae encontral-o vacilante e acabrunhado, pensando como há de sustentar a prole, com tão mesquinho salário que percebe (e e as vezes não recebe); que não chega a attender as primeiras necessidades do lar. Então pensativo, e dentro do circulo de ferro em que se acha exclama: que miséria! Não tenho dinheiro nem credito!... É uma verdade. Porque se recorre ao taverneiro que é seu amigo (emquanto vir o interesse) e pede-lhe crédito, este logo lhe diz; não posso! Outros dizem sim, mas... exploram tão estupidamente o pobre trabalhador, que não sabe o meio de julgal-o. E, ai daquelle que diz; não posso pagar esta semana; tenha um pouco de paciência. Fica termitantemente cortado, e entregue á sua própria desventura... não sabem elles que o pobre é honrado, e se não lhe poude pagar foi por não ter recebido, ou teve que attender á doença em casa, e o que ganhou, não deu para o medico e a pharmacia. Mas que há de fazer?... O pobre está sujeito a todos esses dissabores!... No entanto, para a burguesia nada se nega, e não se pergunta se pode ou não pagar. Finalmente um prazer na vida, é que a morte quando chega, não escolhe ricos ou humildes, operários ou burgueses, ceifa a todos e quebra a prepotência, indo atirar na valla, para lá se tornar em pó. E lá no tribunal supremo, Deus castiga o mau e premia o bom. Se assim é, tenha fé, paciência e continuemos nossa jornada que mais cedo ou mais tarde, chegará o que aqui na terra não nos querem dar os prepotentes (SÉRVULO, 1920b, p. 2).

Sérvulo escreve essas palavras em um momento de agravamento da crise econômica na região, ou seja, na década de 1920. É possível perceber em seu texto dois aspectos que emergiram nesse contexto de declínio: desemprego e parcos salários. Ambos atingiam de forma dramática, como se pode certificar no texto do referido autor, os trabalhadores, que ficavam numa situação degradante e humilhante.

Por outro lado, Sérvulo não poupou críticas à burguesia, acusada por ele de ser prepotente, arrogante, déspota, opressora e exploradora do suor alheio. Nesse sentido, para o operário sair da situação de miséria que a burguesia lhe inseriu, era essencial uma ação dos trabalhadores em conjunto, unidos, contra a tirania econômica-social dos burgueses. Sérvulo, então, fabricou artigos aludindo à importância da luta operária por melhores dias: 
Luctar, pelejar sem armas com adversários, diversos é para vencer a todos os obstáculos que se aprezentem na lucta. Cabe a todos o dever de luctar para adquirir o pão corporal e o pão espiritual. Devemos todos luctar sem trégoas, com todo o esforço, para retirtar dos nossos companheiros todos os preconceitos e vícios que corrompem o physico, e a moral social. Luctemos, com carinho, amor e energia, pela consummação de nosso ideal. Luctemos pela causa magna de todos os que soffrem e morrem dia a dia privados de recursos, espoliados de todos os bens, exhaustos de todas as forças [...] Luctemos contra os despotismos da burguezia, que trazem calcados aos pés os nossos direitos. Luctemos pela emancipação do operariado, eternamente perseguido pelos patrões [...] (SÉRVULO, 1920a).

Um aspecto marcante a considerar se refere ao que o autor do texto chamou de "pão corporal" e "pão espiritual". Lutar para instruir-se e, assim, alimentar o espírito para a compreensão do mundo e das ações operárias a serem desenvolvidas seria tão pertinente quanto preparar o corpo (evitando os vícios que o prejudicaria - álcool, por exemplo) para a luta social.

Sobre a questão do corpo operário, Aravanis sublinhou que havia interesse, por parte dos militantes operários no Sul, sobretudo os anarquistas, de preservar o corpo para a luta operária. Para isso, a autora menciona a existência de duas lógicas. A primeira de preparar o corpo para as ações de luta social, demonstrando essa intenção através da imprensa operária gaúcha, explicitando o combate que era realizado, nas páginas desses jornais, contra os baixos salários e a carestia de vida (que impediam uma boa alimentação) e, da mesma forma, contra a extensa jornada de trabalho e os regulamentos de fábrica (que tiravam energia excessiva do corpo). A segunda de propiciar um corpo saudável para que as atividades mentais de compreensão e ação sobre o mundo pudessem fluir de forma significativa (corpo/orgânico - mente/ideia) (ARAVANIS, 2010, p. 169-171). Portanto, a preservação do corpo operário não era algo singular relacionado aos militantes no Amazonas.

Como foi realçado anteriormente, essa liderança escreveu em jornais (Vida Operária e $O$ Extremo Norte), envolveu-se nas comemorações do Primeiro de Maio, organizando o evento e discursando sobre a luta operária, fundou e participou da diretoria do Sindicato dos Cigarreiros e ajudou diversas categorias a criar os seus sindicatos. À vista disso, foi um militante de destaque no cenário local, sendo reconhecido inclusive entre os seus pares: 
Não podemos deixar passar em silêncio a attitude francamente sympathica do nosso esforçado companheiro Manoel Sérvulo. Por iniciativa inteiramente sua, foram organisados os Syndicatos dos Cigarreiros e dos Estivadores; e agora, segundo informações que acabamos de receber, será organisado o dos trabalhadores e magarefes, ainda sobre iniciativa de Manoel Sérvulo. E é de elementos da força desse nosso destemido companheiro que precisamos, para chegarmos ao termino das aspirações da Humanidade [...] (O EXTREMO NORTE, 1920).

Sérvulo desenvolveu sua atividade de militante ao lado de Joaquim Azpilicueta e outros socialistas como Cursino da Gama.

\section{Cursino da Gama}

João Cursino da Gama foi outra liderança que ficou registrada nas páginas da imprensa operária pelas suas ações de militância no Amazonas. Da mesma forma que os anteriores, Gama inseriu-se numa dinâmica de incentivo e orientação organizacional com o objetivo de contribuir para a luta operária (GAMA,1920, p. 1). Movimentou-se entre os diferentes grupos que possuíam inclusive posições divergentes, em grande medida, assim como Joaquim Azpilicueta, estimulando a superarem as suas diferenças e a construírem consensos em torno de questões específicas como, por exemplo, as eleições governamentais (O MOMENTO..., 1920, p. 2). Sobre isso ele sublinhava:

O indifeferentismo do operário as coisas políticas do nosso Estado é um erro irremissível [...] E qual o meio mais viável de cooperarmos nessa tão anciada salvação? Unificando-nos, e correndo as urnas por occasião de ferir-se o pleito governamental, afim de collocarmos um homem que reúna, todos os requisitos indispensáveis a um perfeito chefe de Estado [...] justo, intelligente, honrado [...] (GAMA, 1920, p. 1). 
Esse artigo foi publicado momentos antes das eleições estaduais ocorrerem, cenário que fez com que Gama externasse aquilo que ele via como fundamental: eleger um "chefe de Estado" que, para além dos adjetivos frisados, atendesse as reivindicações dos trabalhadores - oito horas de trabalho, intermediação do estado na relação capital/trabalho, promoção da estabilidade no emprego, etc.

Mas não era somente isso que ele defendia. Ainda fazendo sobressair sobre os seus escritos às eleições político-partidárias, apontou a criação e a consolidação de um partido operário no Amazonas como ponto fulcral da luta:

No próximo domingo, 7, às nove horas, terá logar, no Theatro Alcazar, gentilmente cedido pelo seu illustre proprietário dr. Raymundo Fontenelle, a primeira reunião operária para a fundação do Partido Operário Amazonense.

Como medida de precaução, o nosso companheiro Cursino Gama, previne a todos os nossos companheiros de classe, que o futuro P. O. A. nenhuma ligação terá com as diversas aggremiações políticas, que se degladiam no Estado; bem assim que somente aos operários no goso de seus direitos civis e políticos, como cidadãos brazileiros, será permittido filiarem-se a esse Partido, de accordo com a Constituição Federal Brazileira, quer sejam ou não eleitores.

Todos os operários, trabalhadores, etc. devem comparecer a essa reunião, aonde serão apresentadas as bases para a organisação do mesmo.

$[\ldots]$

Que seja coroado de bom êxito o primeiro passo dos nossos companheiros, em prol da emancipação operária local, são nossos votos (GAMA, 1920, p. 1).

Consoante Gama, o P. O. A. teria que ser composto somente por trabalhadores, para defender a causa operária. Na luta operária, como ressaltou Pinheiro e Pinheiro, "acompanhou de perto as manifestações e greves de diversas categorias, como a dos estivadores, carroceiros ou dos motoristas de bondes da Manaós Tramways", pautando-se "sempre pela moderação", condenando até mesmo a deflagração de greves. Agia como um conciliador, indicando continuamente a "negociação com o patronato" (PINHEIRO; 
PINHEIRO, 2017, p. 212-213). Mergulhou ativamente na produção de folhas operárias, especialmente nos jornais Extremo Norte e Vida Operária, onde colaborava. No ano de 1928, foi o responsável direto pela publicação de um número especial em comemoração ao dia Primeiro de Maio.

É oportuno sublinhar que a militância de Gama extrapolou os anos 20, avançando pela década de 30. De acordo com Pinheiro e Pinheiro, a sua carreira política:

[...] tanto no meio operário, quanto na política partidária avançaria ao longo da década de 1920.

$[\ldots]$

No campo da política partidária, aproximou-se das oligarquias, associando a Efighenio Salles (Governador do estado), Araújo Lima (Prefeito de Manaus) e Monteiro de Souza (Presidente da Assembleia Legislativa), homenageando-os em seu jornal. Por fim, elegeu-se vereador da cidade em 1929, mantendo-se como membro da edilidade até pelo menos 1935 (PINHEIRO; PINHEIRO, 2017, p. 213).

Assim, João Cursino da Gama marcou presença no universo do trabalho urbano em Manaus.

\section{Nicodemos Pacheco}

Nicodemos Pacheco fazia parte do Sindicato dos Cigarreiros, assim como Cursino da Gama, e colaborava na imprensa operária, particularmente no jornal Vida Operária. Nele fabricou textos, alguns publicados, versando sobre a importância do operário - enquanto elemento fundamental e dinâmico na produção das riquezas - no mundo "moderno", como se constata a seguir:

A "Reacção" comentando o telegramma do agente da american, sobre a organização do Partido Operário, passado para o Rio, que calculava que 
o mesmo partido apoiaria um dos candidatos a curul governamental, diz: - São esses os valiosos elementos que conta o dr. Rego Monteiro, etc. Porque gripharam valiosos, quando referiram-se aos operários.

Que diferença há entre nós operários, e os srs. reacionários, burocratas e co mandita.

Pela lei natural das coisas e perante a nossa Constituição, não conheço doutores, nem tão pouco coronéis.

Diante da sociedade mundana, vejo, esses srs. como parasitas do braço trabalhador.

Perante a lei da evolução, vejo o operário que constróe, edifica e aplaina o direito no caminho da verdade.

O operário, no seu constante e laborioso trabalho, vive para a humanidade e os parasitas vivem da humanidade.

Pois bem, se qualquer candidato estivesse amparado pelo operariado, estaria apoiado por um VALIOSO elemento, de actos dignificadores e nobres, que não vende a sua consciência e a sua palavra por meia pataca, porque ganham o pão de cada dia com o suor de seu rosto.

O operário, para viver, tem independência, e não precisa conchavos machiavélicos de política nojenta.

Que diferença há entre os operários e os burocratas.

Muita; os primeiros, são trabalhadores e honestos e os outros, ambiciosos, prepotentes e pouco escrupulosos, a bem dos seus interesses (PACHECO, 1920, p. 1).

Identifica-se uma valorização do trabalho no texto de Pacheco, que claramente foi elaborado para responder ao jornal Reacção e sua postura deselegante e irônica com relação aos trabalhadores, mas reveladora de como a elite extrativista/comercial no Amazonas os via: como algo menor. $\mathrm{E}$ quando eles não correspondiam às diretrizes estabelecidas por uma ética de trabalho burguesa, disciplinadora e controladora, por excelência, eram taxados de "indolentes" e "preguiçosos". O quadro se agravava mais ainda quando os operários participavam nas suas associações e faziam greves, aí eram tidos como "baderneiros". Sobre esta questão, Avelino expôs que: 
A visão depreciativa sobre os trabalhadores foi uma constante em todo momento da relação entre patrões e empregados em Manaus [...]. O trabalhador era na maioria das vezes identificado mais pelos seus estereótipos de preguiçoso e vadio do que pelas sua qualidades pessoais e técnicas (AVELINO, 2008, p. 71).

A grande preocupação de Nicodemos Pacheco era buscar um reconhecimento da importância dos trabalhadores para a sociedade em geral.

\section{O ponto de encontro dos quatro socialistas: Centro Operário Amazonense, União Operária Nacional do Amazonas e Partido Operário Amazonense}

Os quatro militantes aqui reportados atuaram juntos em alguns momentos, sobretudo nos anos de 1920, e se encontraram, notadamente, quando deixaram de falar para as suas respectivas categorias através das suas associações e passaram a agir com a finalidade de se direcionar aos trabalhadores como um todo, amplificando suas vozes para atingir o conjunto do operariado.

Nesse processo, algumas instituições foram fundadas por eles e se colocaram como pilares desse encontro: o Centro Operário Amazonense, a União Operária Nacional do Amazonas e o Partido Operário Amazonense. O primeiro foi fundado em 1917. A sua finalidade era atingir o operariado amazonense indistintamente (todas as categorias) e incorporar os grupos de outros segmentos sociais, como comerciantes, políticos, advogados, médicos, dentre outros. O Centro buscava a colaboração entre as classes, "ignorando termos como greve, luta operária e ação direta" para enfatizar a negociação e a prudência (PINHEIRO; PINHEIRO, 2017, p. 194). Pouca coisa se sabe sobre a União, porém não restam dúvidas de que ela possuía uma posição política diferente da do Centro, sendo mais restrita, no campo organizacional, ao operariado. Por fim, o Partido Operário Amazonense, que era visto pelas quatro lideranças socialistas em tela como um instrumento de inserção política no jogo eleitoral na Primeira República, por onde se colocaria e defenderia, via parlamento, as questões levantadas como bandeira de luta pelos operários.

Nesse processo, Joaquim Azpilicueta, Manoel Sérvulo, Nicodemos Pacheco e Cursino da Gama, juntamente com outros militantes, envolveram-se de maneira intensa, dando seguimento à luta daqueles primeiros socialistas que sublinhamos na parte inicial deste 
artigo. Esses nomes, por exemplo, fizeram-se ativos na "greve geral" ocorrida em 1919 em favor da jornada de oito horas de trabalho (alvo de manifestações idênticas no sul e sudeste do país). Para conduzir a greve foi formado um "Comitê de Operários Amazonenses". A formação dele incorporava os personagens acima, além de outros (PINHEIRO, 1999, p. 171178).

O que se quer frisar é que eles estiveram juntos nesses projetos de participação e ações políticas voltados aos trabalhadores, circulando nas associações, no partido, no Centro e na União, fazendo análises sociais e proferindo palavras de luta. O trecho abaixo é esclarecedor dessas atividades:

Em o dia 25 do mez p. findo foi este Centro visitado por um dos nossos companheiros de redacção que ali fora em propaganda deste órgão.

Recebido distinctamente pelos camaradas em plena sessão, após a leitura do expediente, de posse da palavra expos numa brilhante allocução o fim de sua visita:

Entre outras cousas, disse o nosso companheiro, que se achando operariado amazonense organisado e forte, tronava-se preciso antes de tudo, manter em nosso meio um jornal que fosse sua legítima defesa, sendo as sua últimas palavras abafadas por uma estrondosa salva de plamas.

Terminada a sessão, os camaradas dessa bem organisada sociedade, manifestando a mais clara satisfação, acompanharam o nosso companheiro até a porta, de uma maneira que só podemos agradecer (CENTRO...,1920, p. 1).

Esse exemplo é emblemático de como não se pode compreender a imprensa operária dissociada do tripé que foi enfatizado anteriormente, qual seja: associações, partidos e imprensa. Ele também possibilita uma espécie de visita ao Centro Operário Amazonense no sentido de sentir um pouco do que acontecia nesse espaço.

$\mathrm{Na}$ criação do partido operário, em 1920, dois desses militantes socialistas compareceram nas discussões que antecederam a sua fundação: 
No domingo p. p. realisou-se a primeira reunião annunciada no theatro Alcazar para a fundação do Partido Operário Amazonense. As 9 1/2 horas da manhã, na presença de um avultado número de operários, o sr. Cursino Gama, abriu a sessão, expondo aos assistentes o fim da reunião, e em seguida deu a palavra a quem della quizesse fazer uso.

Falaram os operários Nicolau Pimentel, Raymundo Rodrigues, Anacleto José dos Reis e Nicodemos Pacheco.

Depois de alguns debates, foi approvado a fundação do partido, adherindo a idéia, a totalidade dos assistentes.

Hoje as mesmas horas e no thetro Odeon deverá se realisar nova reunião, afim de ser approvada a regulamentação do Partido.

Concitamos ao operariado em geral para comparecer a reunião de hoje.

Esta redacção fez-se representar pelo nosso diretor (VIDA OPERÁRIA, 1920b, p. 1)

Tudo leva a crer que pelo circuito que eles percorriam e pelo projeto politico que defendiam, a ausência de seus nomes (Joaquim Azpilicueta e Manoel Sérvulo) na passagem acima pode ser explicada pelo fato de não terem, nessa ocasião, discursado. De qualquer forma, fica evidente que esses espaços criados por eles eram também pontos de conexão e encontro dos mesmos.

\section{Considerações finais}

As quatro lideranças acentuadas no presente texto tiveram um papel significativo na dinâmica do movimento operário socialista local, pois, como se pôde notar, buscaram organizar os trabalhadores no Amazonas. Na esteira da experiência socialista do final do século XIX, registrada nos jornais Gutenberg e Operário, não deixaram de agir no sentido de organizar as variadas categorias profissionais em torno de associações, a exemplo dos estivadores, de criar e colocar para circular uma imprensa destinada ao mundo do trabalho e suas demandas, de fundar o Partido Operário Amazonense e, certamente, com isso, de acalentar o sonho de conduzir os operários para uma melhor situação social. 
A articulação e interação entre eles podem ser averiguadas pelo fluxo de alguns deles, como por exemplo, Manoel Sérvulo da Silva e João Cursino da Gama, personagens centrais desse momento, que participaram, como se viu, na elaboração de artigos, destinados ao processo organizativo das categorias e a participação político-partidária, publicados tanto no jornal Vida Operária quanto no Extremo Norte. Ambos ainda fundaram associações, por onde circulavam proferindo discursos sobre a luta dos trabalhadores contra ao que chamavam de precárias condições de vida e trabalho. Além de associações voltadas para categorias específicas, como o Sindicato dos Cigarreiros, do qual Manoel Sérvulo fazia parte, também participaram de organismos de caráter mais amplo e pluriclassistas, como o Centro Operário Amazonense, a União Operária Nacional do Amazonas e o Partido Operário Amazonense (TELES, 2008, p. 143-145), instituições à espera de algum pesquisador.

\section{Referências}

ARAVANIS, Evangelia. A industrialização no Rio Grande do Sul nas primeiras décadas da República: a organização da produção e as condições de trabalho (1889-1920). Revista Mundos do Trabalho, Florianópolis, v. 2, n. 3, p. 148-180, jan./jul. 2010.

AVELINO, Alexandre Nogueira. O patronato amazonense e o mundo do trabalho: a revista da Associação Comercial e as representações acerca do trabalho no Amazonas (1908-1919). Dissertação (Mestrado em História) - Universidade Federal do Amazonas, Manaus, 2008.

AZPILICUETA, Joaquim. Impressões. A Lucta Social, Manaus, ano 1, n. 3, p. 7-8, 1 jun. 1914.

AZPILICUETA, Joaquim. O operário é o mundo. O Primeiro de Maio, Manaus, ed. Esp., p. 4, 1 maio 1928.

BAHIA, Juarez. Jornal, história e técnica: história da imprensa brasileira. 4. Ed. São Paulo: Ática, 1990.

BATALHA, Cláudio Henrique de Moraes. Identidade da classe operária no Brasil (18801920): atipicidade ou legitimidade. Revista Brasileira de História, São Paulo, v. 12, n. 23, p. 111-124, set./ago.1992.

BATALHA, Cláudio Henrique de Moraes. Vida associativa: por uma nova abordagem da história institucional nos estudos do movimento operário. Anos 90. Porto Alegre, n. 8, p. 91-99, dez. 1997.

BILHÃO, Isabel Aparecida. "Informar" para "formar": reflexões sobre imprensa e militância no mundo do trabalho brasileiro na Primeira República. Cadernos de História, Belo Horizonte, v. 16, n. 24, p. 138-156, 2015. 
CENTRO Operário do Amazonas. Vida Operária, Manaus, ano I, n. 2, 15 fev. 1920.

COSTA, Francisca Deusa Sena. Quando viver ameaça a ordem urbana: cotidiano de trabalhadores em Manaus, 1915-1925. Dissertação (Mestrado em História) - Pontifícia Universidade Católica, São Paulo, 2000.

CRUZ, Heloisa de Faria. São Paulo em papel e tinta: periodismo e vida urbana (1890-1915). São Paulo: EDUC, 2000.

CRUZ, Manuel Carvalho Ferreira. O movimento libertário portuense à luz do periódico $A$ Aurora (1910-1919). Dissertação (Mestrado em História) - Universidade do Porto, Porto, 2012.

DECCA, Maria Auxiliadora Guzzo. A vida fora das fábricas: cotidiano operário em São Paulo, 1920-1934. Rio de Janeiro: Paz e Terra, 1997.

DIAS, Ednéa Mascarenhas. A ilusão do fausto: Manaus, 1890-1920. Manaus: Valer, 1999.

FERREIRA, Maria Nazareth. Imprensa operária no Brasil. São Paulo: Ática, 1988.

GAMA, João Cursino. A posto! O Extremo Norte, Manaus, ano 1, n. 13, p. 1, 8 abr. 1920.

GONÇALVES, Adelaide (Org.). Ceará socialista - anno 1919. Florianópolis: Insular, 2001.

GUTENBERG. Manaus, ano 1, n. 19, p. 3, 1 maio $1892^{\text {a }}$.

GUTENBERG. Manaus, ano 1, n. 25, 1 jul. 1892b.

LUCA, Tânia Regina. A grande imprensa na primeira metade do século XX. In: MARTINS, Ana Luiza; LUCA, Tânia Regina de. História da imprensa no Brasil. São Paulo: Contexto, 2008. P. 149-175.

MACIEL, Osvaldo Batista Acioly. Filhos do trabalho, apóstolos do socialismo: os tipógrafos e a construção de uma identidade de classe em Maceió (1895-1905). Dissertação (Mestrado em História) - Universidade Federal de Pernambuco, Recife, 2004.

MOVIMENTO Typographico. Gutenberg. Manaus, ano 1, n. 1, 15 nov. 1891

NOTICIÁRIO. Vida Operária, Manaus, ano I, n. 10, 11 abr.1920.

O EXTREMO NORTE. Manaus, ano 1, n. 21, 5 jun. 1920.

O MOMENTO. Vida Operária, Manaus, ano I, n. 9, 4 abr. 1920.

PACHECO, Nicodemos. Bilhete aos reaccionários. Vida Operária. Manaus, ano 1, n. 20, p. 1, 11 jul. 1920.

PANSARDI, Marcos Vinícius. O movimento operário e a República. Estudos de Sociologia, Araraquara, v. 3, n. 5, p. 87-99, 2008. 
PANSARDI, Marcos Vinícius. O socialismo dos modernos e o socialismo dos antigos: a incorporação do vocabulário ideológico da II Internacional pelo movimento socialista brasileiro. História Social, São Paulo, n. 1, p. 65-94, 1994.

PARTIDO Operário. Gutenberg, Manaus, ano I, n. 25, 1 jul. 1892.

PINHEIRO, Luís Balkar Sá Peixoto. Lideranças estrangeiras entre os trabalhadores manauaras (1910-1930). Revista Mundos do Trabalho, Florianópolis, v. 9, n. 17, p. 79-100, jan./jul. 2017.

PINHEIRO, Luís Balkar Sá Peixoto; PINHEIRO, Maria Luiza Ugarte. Mundos do trabalho na cidade da borracha: trabalhadores, lideranças, associações e greves operárias em Manaus (1880-1930). Jundiaí: Paco Editorial, 2017.

PINHEIRO, Maria Luiza Ugarte. A cidade sobre os ombros: trabalho e conflito no porto de Manaus (1899-1925). Manaus: Edua, 1999.

PINHEIRO, Maria Luiza Ugarte. Vivências urbanas: o cotidiano de trabalhadores na contramão dos processos de modernização em Manaus. Fronteiras do Tempo, Manaus, v. 1, n. 2, p. 1-15, dez. 2011.

PORTO, Santos. Governo do terror I. Operário, Manaus, ano 1, n. 1, p. 3, 12 dez. 1892 .

PORTO, Santos. Governo do terror II. Operário, Manaus, ano 1, n. 2, p. 3, 19 dez. 1892b.

RAGO, Margareth. Do cabaré ao lar: a utopia da cidade disciplinar, Brasil (1890-1930). Rio de Janeiro: Paz e Terra, 1985.

Referências

SCHMIDT, Benito Bisso. A palavra como arma: uma polêmica na imprensa operária porto-alegrense em 1907. História em Revista, Pelotas, n. 6, p. 59-84, 2000.

SÉRVULO, Manoel. Luctemos. O Extremo Norte, Manaus, ano 1, n. 22, 12 jun 1920a.

SÉRVULO, Manoel. Palavras simples. Vida Operária, Manaus, ano 1, n. 6, p. 2, 14 mar. 1920b.

SODRÉ, Nelson Werneck. História da imprensa no Brasil. 4. Ed. Rio de Janeiro: Mauad, 1999.

SOMOS operários. A Lucta Social, Manaus, ano I, n. 1, 29 mar. 1914.

TELES, Luciano Everton Costa. A vida operária em Manaus: imprensa e mundos do trabalho (1920). Dissertação (Mestrado em História) - Universidade Federal do Amazonas, Manaus, 2008.

TELES, Luciano Everton Costa. Entre perseguições, agressões e empastelamentos: o caso dos jornais de trabalhadores Gutenberg (1891-1892) e Operário (1892) no Amazonas na Primeira República Brasileira. Aedos, Porto Alegre, v. 7, n. 17, p. 22-40, dez. 2015. 


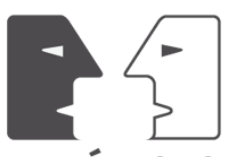

ANTÍTESES

THOMPSON, Edward Palmer. A formação da classe operária inglesa. Rio de Janeiro: Paz e Terra, 1987.

VIDA OPERÁRIA. Manaus, ano 1, n. 18, p. 1, 13 jun. $1920 \mathrm{~b}$.

VIDA OPERÁRIA. Manaus, ano 1, n. 7, p. 1, 21 mar. $1920^{\mathrm{a}}$.

ZICMAN, Renée. História através da imprensa: algumas considerações metodológicas. Projeto História, São Paulo, n. 4, p. 89-102, 1985.

Recebido em 18/5/21017

Aprovado em 14/02/2018 